\title{
Red-baiting in tooth and claw
}

\author{
Review of Weinberg, C. 2021. Red Dynamite: Creationism, Culture wars, and \\ Anticommunism in America. Cornell University Press, Ithaca (NY)
}

Glenn Branch* ${ }^{*}$

\begin{abstract}
Throughout the twentieth century, Carl Weinberg explains in Red Dynamite: Creationism, Culture Wars, and Anticommunism in America, American antievolutionists regularly attempted to vilify evolution through its supposed association with communism. His book is a splendid chronicle of the deployment and development of their claims.
\end{abstract}

Keywords: Creationism, Anticommunism

Reporting on the Scopes trial from Dayton, Tennessee, H. L. Mencken blandly claimed, "News came the other day to Pastor T. T. Martin, who is holding a continuous anti-evolution convention in the town, that a party of I.W.W.s [i.e., members of the left-leaning Industrial Workers of the World], their pockets full of Russian gold, has started out from Cincinnati to assassinate him. A bit later came word they would bump off [William Jennings] Bryan after they had finished Martin, and set fire to the town churches" (Mencken 2006, p. 70). Guards were posted, but the Wobbly forces were never spotted. In fact, it was Mencken himself and his colleague Henry M. Hyde who warned Martin of the threat, as a practical joke. Martin was so panicked, Mencken later recalled, that he swiftly forgot its source: "An hour later, in fact, when Hyde and I met him again, he imparted it to us as news, and we thanked him very politely" (Mencken 1943, p. 230). Yet Martin enjoyed the last laugh: in 1927, he successfully lobbied the Mississippi legislature to enact a ban on teaching evolution similar to Tennessee's that remained in force till 1970.

Martin was hardly alone in his willingness to credit a sinister link between evolution and the political left. Even during Darwin's lifetime, the reviewer of The Descent of

*Correspondence: branch@ncse.ngo

National Center for Science Education, 230 Grand Avenue, Suite 101,

Oakland, CA 94610, USA
Man for the Times of London complained that Darwin's evolutionary account of morality, if widely accepted, would mean that "conscience would cease to be a check upon the wildest, or as Mr. Darwin's own illustration allows us to add, the most murderous revolutions," soon thereafter citing "the disorganisation of French society" ([Wace] 1871). The review appeared just weeks after the rise of the Paris Commune-and just weeks before its fall. Not so transient, however, were the effects of the Bolshevik Revolution in Russia in 1917 and the establishment of the Soviet Union in 1922. As a result, as Carl Weinberg explains in the introduction of his Red Dynamite, American "antievolutionists throughout the twentieth century mobilized their followers by linking evolution, communism, and immorality" (p. 13). His book is a splendid chronicle of the deployment and development of their claims.

William Bell Riley, a Baptist preacher who was as responsible for the launch of the antievolution crusade of the 1920s as anyone, may have been the first prominent figure to link evolution and communism, in a 1923 sermon, but Weinberg plausibly suggests that the linkage was solidified by George McCready Price. A selfeducated geologist and devout Seventh-Day Adventist, Price not only rejected evolution but also insisted on a young earth and the geological importance of Noah's flood. These were minority views among antievolutionists in Price's day, but after they were repackaged by John original author(s) and the source, provide a link to the Creative Commons licence, and indicate if changes were made. The images or other third party material in this article are included in the article's Creative Commons licence, unless indicated otherwise in a credit line to the material. If material is not included in the article's Creative Commons licence and your intended use is not permitted by statutory regulation or exceeds the permitted use, you will need to obtain permission directly from the copyright holder. To view a copy of this licence, visit http://creativecommons.org/licenses/by/4.0/. The Creative Commons Public Domain Dedication waiver (http://creativeco mmons.org/publicdomain/zero/1.0/) applies to the data made available in this article, unless otherwise stated in a credit line to the data. 
C. Whitcomb Jr. and Henry Morris in The Genesis Flood, with minimal credit to Price, they captured the majority. Weinberg devotes chapter 2 mainly to Price, portraying him as "a creationist pioneer on both the geological and political frontiers" (p. 55), and convincingly tracing how his political views both hardened and became intermingled with his scientific views, resulting in a chapter in his 1925 book The Predicament of Evolution that provides Weinberg with his title: "Red Dynamite."

Subsequent chapters follow the Red Dynamite theme through the century. Creationists are prominently featured, from the pistol-packing pastor Frank Norris and the Catholic theologian George Barry O'Toole through Whitcomb and Morris to the Berkeley law professor Phillip Johnson and the entrepreneurial Australian Ken Ham. Particularly interesting was the discussion of Riley's protégé Dan Gilbert, who specialized in attacking higher education; his influence waned, Weinberg speculates, because of the scandal of his death: he was murdered by his lover's husband. Also included are fundamentalists who invoked the theme although it was not so central to their work, from Gerald Winrod and Aimee Semple McPherson through Carl McIntire and John R. Rice to Tim LaHaye, Jerry Falwell, and Pat Robertson. It was disconcerting to learn that the young Billy Graham preached, "the basis for all the false teaching today is evolution, which denies the existence of God Almighty" (p. 152): he soon abandoned his opposition to evolution thanks to his exposure to the "proto-theistic evolutionism" of Bernard Ramm.

The treatment is both engaging and compendious, although it is a bit surprising that in the discussion of Jerry Falwell, there is no mention of what was probably the most significant episode in his campaign against evolution, perhaps because Weinberg ends the discussion circa 1980. Two years later, Falwell declared that he hoped for the graduates of his Liberty Baptist College (later Liberty University) to "go out into the classrooms teaching creationism ... Of course they'll be teaching evolution. But teaching why it's invalid and why it's foolish" (Isikoff 1982). As a result, there was a tussle over the certification of Liberty's teacher education programs for the better part of three years. Eventually, Liberty agreed not to teach creationism in the biology department. Undeterred, Falwell relocated the creationism courses to a new academic unit, called the Center for Creation Studies. "Creation would be taught to all students as fact, and evolution as an unproven theory ... to all biology students," enabling the latter to become credentialed as public school biology teachers (Harding 2000, p. 219).
Weinberg repeatedly acknowledges that communists and evolutionists sometimes helped to light the fuse for these attacks. The first chapter of Red Dynamite addresses Marx's and Engels's professed enthusiasm for Darwin, inherited by their followers in Russia and the United States alike. Later Weinberg observes that Scopes's father Thomas Scopes was a socialist and was outed as such during the Scopes trial. Although a column by Scopes himself was printed in the communist Daily Worker at the same time, Weinberg is hesitant to infer anything about his political views, perhaps unaware that he ran in Kentucky as a Socialist candidate for Congress in 1932 (LaFollette 2008, p. 122), receiving 0.04\% of the vote. Later in the century, the evolutionists Stephen Jay Gould, Richard Lewontin, and Richard Levins would add fuel to the flames, not only by expressing their sympathies for the political left but also by occasionally suggesting that there were important connections between their political and their scientific views-though Gould, at least, later distanced himself from such claims.

Although Weinberg discusses the communist-activistturned-science-journalist Ludwig Katterfield at length, it's a shame that he omits the socialist-activist-turnedscience-journalist Maynard Shipley, still remembered for writing The War on Modern Science and founding the Science League of America to advocate the teaching of evolution. Earlier, however, Shipley was active in socialist circles on the West Coast, having been converted to the cause by reading Oscar Wilde's "The Soul of Man under Socialism," and ran in California as a Socialist candidate for Congress in 1920. His socialism returned to haunt him at the Science League of America, according to his biographer (and third wife). "One of the most notorious 'professional patriots' in the country-a Philadelphia stockbroker [probably Francis Ralston Welsh]-and a Washington magazine that was covertly a semi-organ of the Ku Klux Klan [probably The Fellowship Forum]" prepared "indictments" of Shipley based on his socialist past, only to be dissuaded by the threat of legal action (deFord 1956, p. 214).

Three probably unavoidable limitations of Red Dynamite deserve mention. First, Weinberg maintains a narrow focus, only rarely, as in his discussion of Ronald Reagan, considering broader currents in American anticommunism. A diligent reader might want to consult a general history of anticommunism in the United States (such as Ceplair 2011) in order to calibrate creationist anticommunism against a baseline. Second, except for dispelling the myth that Marx offered to dedicate Das Kapital to Darwin (debunked in Fay 1978), Weinberg never offers to evaluate the arguments linking evolution 
and communism. Perhaps the thought is that the arguments presented by his subjects are generally unconvincing on their face-which is plausible; they rarely rise above the level of anecdote. Third, in light of the weakness of these arguments, it is tempting to wonder to what extent their proponents sincerely regarded communism as entwined with evolution as opposed to a convenient stick with which to belabor it. Understandably but regrettably, Weinberg makes no attempt to read their minds.

The Red Dynamite theme started to fizzle in the early $1980 \mathrm{~s}$, when creationists (following in the footsteps of Tim LaHaye) gradually pivoted to regard secular humanism rather than communism as their bête noire. It is suggestive that although the Kitzmiller v. Dover trial in 2005 apparently elicited two books (Skybreak 2006; Foster et al. 2008) defending evolution by authors affiliated with communist and socialist organizations, there was virtually no reaction from the creationist establishment. Yet Weinberg provides plenty of evidence of the theme's continuing, if muted, presence into the present century: creationism and anticommunism accompanied Mike Pence, Betsy DeVos, and Ben Carson to the Trump White House. Today, when what Weinberg describes as "redbaiting, antisocialist, anti-Marxist politics" (p. 282) aimed at public education unfortunately seems to be enjoying a revival, understanding the history of attempts to vilify evolution through its supposed association with communism will not only inform evolution educators about the past but also equip them to cope with the future.

\section{Acknowledgements}

Thanks to Ann Reid for comments on a draft.

\section{Authors' contributions}

GB is the sole author of the article. The author read and approved the final manuscript.

\section{Funding}

Not applicable.

\section{Availability of data and materials}

Not applicable.

\section{Declarations}

Ethics approval and consent to participate Not applicable.

\section{Consent for publication}

Not applicable.

\section{Competing interests}

The author declares that he has no competing interests.

Received: 18 November 2021 Accepted: 19 November 2021 Published online: 13 December 2021
References

Ceplair L. Anti-communism in twentieth-century America: a critical history. Santa Barbara (CA): Praeger; 2011.

deFord MA. Up-hill all the way: the life of Maynard Shipley. Yellow Springs $(\mathrm{OH})$ : Antioch Press; 1956.

Fay MA. Did Marx offer to dedicate Capital to Darwin? a reassessment of the evidence. J. Hist. Ideas 1978; 39(1): 133-146.

Foster JB, Clark B, York R. Critique of intelligent design: materialism versus creationism from antiquity to the present. New York: Monthly Review Press; 2008.

Harding SF. The book of Jerry Falwell. Princeton (NJ): Princeton University Press: 2000.

Isikoff M. Liberty Baptist approved as biology teacher source. The Washington Post. 1982. p. B1.

LaFollette MC. Reframing Scopes: journalists, scientists, and lost photographs from the trial of the century. Lawrence (KS): University Press of Kansas; 2008.

Mencken HL. Inquisition. In: Mencken HL. Heathen days. New York: Alfred A. Knopf; 1943. p. 214-238.

Mencken HL. Law and freedom, Mencken discovers, yield place to holy writ in Rhea County. In: Mencken HL. A religious orgy in Tennessee: a reporter's account of the Scopes monkey trial. Brooklyn (NY): Melville House; 2006. p. 67-74.

Skybreak A. The science of evolution and the myth of creationism: knowing what's real and why it matters. Chicago: Insight Press; 2006.

Wace H. Mr. Darwin on the descent of man. The Times. 1871. p. 3, 5.

\section{Publisher's Note}

Springer Nature remains neutral with regard to jurisdictional claims in published maps and institutional affiliations.

Ready to submit your research? Choose BMC and benefit from:

- fast, convenient online submission

- thorough peer review by experienced researchers in your field

- rapid publication on acceptance

- support for research data, including large and complex data types

- gold Open Access which fosters wider collaboration and increased citations

- maximum visibility for your research: over 100M website views per year

At BMC, research is always in progress.

Learn more biomedcentral.com/submissions 